clearly prove it to be Muschelkalk. It appears that the $\mathrm{K}$ euperin the neighbourhood of the Lakes of Lugano and Como is also in the state of dolomite, which renders it difficult to separate it from the dolomites which underlie the Muschelkalk; the Lower Lias is well developed at Arzo, Saltzio, and at Monte Generoso near Mendrisio, and on the shores of the Lake of Como. Then follow, forming an extensive horizon, the beds of the Calcareo ammonitifero rosso, of Erba, \&c., which evidently belong to the Etage Toarcien of D'Orbigny, and which can be traced over a considerable portion of Italy.

Basle, April 9, 1854.

[Note.-Compare Escher von der Linth "on the Vorarlberg," Mém. Soc. Helv. vol. xiii.; and Quart. Journ. Geol. Soc. No. 42. Miscell. pp. 16, \&c. ; Suess " on the Vorarlberg," and " on the Kössen Brachiopods," ibid. No. 43. Miscell. p. 25, \&c.; and Von Hauer "on the Trias, Lias, and Jura of the Eastern Alps," Jarhb. K. K. Geol. Reichsanst. 1853, pp. 715, \&c. ; and the Anniversary Address, 1855, Quart. Journ. Geol. Soc. No. 42. pp. lxiii, \&c.-ED.]

\title{
3. Notice of some Cretaceous Rocks near Natal, South Africa.
} By R. J. Garden, Esq., late Capt. H.M. 45th Reg.

[Communicated by R. Godwin-Austen, Esq., F.G.S.]

[Abstract.]

The discovery of these fossiliferous rocks, near the Umtafuna* (on some maps spelt "Umtavooma") River, on the coast of South Africa, was made by Mr. H. F. Fynn, in 1824. About three miles to the southward of the river commence certain excavations in the cliffs, formed by the action of the sea, and called by the natives "Izinhluzabalungut." These caves extend for about 800 yards. In 1851 Capt. Garden visited the spot with Mr. Fynn, and, with the aid of his servant (the late Private Thomas Souton), and the natives, collected a suite of fossils $\downarrow$ from the walls of the caves and from the adjoining cliffs. The cliffs vary considerably in height, and their tops are covered with vegetation; the Strelitzia alba grows abundantly in the hollows. The lowest rock visible is a hard shelly rock with pebbles; above it is a brownish-red sandstone, traversed in every direction with white veins, which are the broken edges of colossal bivalve shells (Inoceramus). These shells are thin, and too easily broken to be extracted from the rock; the corrugated surface of a portion of one was exposed to the extent of 2 feet in length by 1 foot in breadth, and the author estimated others to be nearly 3 feet in length. This shell is common to all the strata in the cliff. Alternate layers of the above-mentioned two rocks occur to the height of about 18 feet; above which are hard bluish-black, brown,

* Pronounced Oom-tā-fū-nã.

† Pronounced Izĭnthlū zābālūngū : " the houses of the white men ;" so called probably from the caverns having once been occupied by shipwrecked sailors.

$\ddagger$ These fossils are described by Mr. Baily in the next following communication. 
and greenish argillaceous and sandy beds. Shells were found in all these clay-beds, and Ammonites at different heights and in certain of the strata. Many fossils are exposed on the cliffs, and washed out on to the shore by the action of the sea.

Fossil trees are seen at low water on a reef of flat rocks near these caverns ; and about three miles to the southward Capt. Garden found at the extreme point of the left bank of the Umpahlanyani* streain a piece of fossil wood, imbedded in a rock similar to that at the caves.

About half a mile beyond the caves runs the Umzambanit River, across which the cretaceous rocks are continued, appearing on its right bank ; after which they are lost sight of, except at a few places : the author, however, believes this formation to extend as far as the Umtata River, having been informed by the late Mr. W. H. D. Fynn that fossil Turtle remains were to be procured from the rocks at the mouth of that river.

4. Description of some Cretaceous Fossils from South Africa ; collected by Capt. Garden, of the 45 th Regiment. By William H. BAILY, Esq., of the Geological Survey of Great Britain.

[Communicated by R. Godwin-Austen, Esq., F.G.S.]

[Plates XI. XII. XIII.]

The late Professor Edward Forbes having entrusted to my examination the interesting series of fossils collected on the coast of South Africa, near Natal, and brought to England by Capt. Garden t, to whose exertions and liberality we are indebted for this valuable addition to the Colonial Department of the Museum of Practical Geology, the following communication has been drawn up on the plan of Prof. Forbes's able "Report on the Fossil Invertebrata from Southern India $\S, "$ to which collection of fossils the series here described bears a close affinity, as also to the fossils from the greensand of Blackdown in our own country, and the Craie Chloritée of France.

\section{Cephalopoda.}

Genus Ammonites, Auctorum.

There are four species of Ammonites in this collection; the specimens generally are in fine preservation, and of remarkable size and beauty, some of them having portions of the shell still adhering. All are allied to Cretaceous forms, and belong to the following groups :-

* Pronounced Oom-pā-thlān-yā-nì.

+ Pronounced Oom-zām-bā-nĭ.

$¥$ See above, p. 453. This collection was briefly noticed in the Rep. Brit. Assoc. 1854, Transact. Sect. p. 83.

$\S$ Transactions Geol. Soc., 2nd Series, vol. vii. 